\title{
EFEK ANTIHIPERURISEMIA EKSTRAK ETANOL DAUN MAHKOTA DEWA (Phaleria macrocarpa) Scheff. Boerl.) PADA MENCIT PUTIH (Mus musculus)
}

\author{
Aisyah Anasia Apriani*, Wisnu Cahyo Prabowo, Arsyik Ibrahim \\ Laboratorium Penelitian dan Pengembangan FARMAKA TROPIS Fakultas Farmasi \\ Universitas Mulawarman, Samarinda, Kalimantan Timur \\ *Email: Anasiaapril24@gmail.com
}

\begin{abstract}
ABSTRAK
Salah satu tanaman yang digunakan masyarakat sebagai obat tradisional untuk asam urat adalah daun mahkota dewa (Phaleria macrocarpa) Scheff. Boerl.). Penelitian ini bertujuan untuk mengetahui rendeman dan metabolit sekunder daun mahkota dewa, mengetahui efek ekstrak etanol daun mahkota dewa (Phaleria macrocarpa)Scheff. Boerl.) serta mencari dosis efektifnya sebagai antihiperurisemia pada mencit betina (Mus musculus), Uji ini dilakukan dengan cara membagi 21 ekor mencit dibagi menjadi 7 kelompok. Tiap kelompok mendapat perlakuan sebagai berikut: Kelompok 1: Kontrol Negatif (Na CMC 0,5\%), Kelompok II: Kontrol Positif (Allopurinol dosis $100 \mathrm{mg} / 70 \mathrm{Kg} \mathrm{BB}$ ), Kelompok IIIVII: Ekstrak etanol dosis 25, 50, 75, 100 dan $125 \mathrm{mg} / \mathrm{Kg}$ BB. Untuk memberikan kondisi Hiperurisemia, hewan coba diinduksi Kalium Oksonat $300 \mathrm{mg} / \mathrm{Kg}$ BB secara ip dan diberikan suspensi hati ayam $1,25 \mathrm{~g} / \mathrm{KgBB}$. Rendemen ekstrak etanol diperoleh sebesar 20,3 \%. Hasil penelitian menunjukkan ekstrak etanol daun mahkota dewa (Phaleria macrocarpa) memiliki efek sabagai penurun asam urat. Analisis statistik dengan uji BNJD menunjukan dosis $50 \mathrm{mg} / \mathrm{Kg} \mathrm{BB}$ adalah dosis efektif sebagai penurun kadar asam urat.
\end{abstract}

Kata Kunci : ekstrak etanol daun mahkota dewa, hiperurisemia, asam urat

\begin{abstract}
One of the plants used by the people as a traditional medicine for gout is mahkota dewa leaves (Phaleria macrocarpa) Scheff. Boerl.). This study aims to determine rendemen and secondary metabolites petals gods, knowing the effect of ethanol extract of leaves of the mahkota dewa leave (Phaleria macrocarpa) Scheff. Boerl.) As well as finding effective dose as antihiperurisemia in female mice (Mus musculus), this test is done by dividing 21 male mice were divided into 7 groups. Each group was treated as follows: Group 1: Negative Control (CMC Na 0,5\%), Group II: Positive Control (Allopurinol 100 mg/ 70 kg BW), Group III-VII: The ethanol extract doses of 25, 50, 75, 100 and $125 \mathrm{mg} / \mathrm{kgBB}$. To give Hyperuricemia conditions, the experimental animals induced Oksonat Potassium 300 $\mathrm{mg} / \mathrm{kgBB}$ intraperitoneally by the suspension of chicken liver $1.25 \mathrm{~g} / \mathrm{KgBB}$. Yield ethanol extract of $20.3 \%$ was obtained. The results showed the ethanol extract of leaves of mahkota dewa (Phaleria macrocarpa) has effect as lowering uric acid. Statistical analysis showed BNJD test dose of $50 \mathrm{mg} / \mathrm{kgBB}$ dose was as effective as lowering uric acid levels.
\end{abstract}

Keywords: ethanol extract of mahkota dewa leave, hyperuricemia, gout 


\section{PENDAHULUAN}

Indonesia merupakan mega senter keragaman hayati dunia, dan menduduki urutan terkaya kedua di dunia setelah Brazil. Di Indonesia diperkirakan hidup sekitar 30.000 spesies tumbuhan, dimana dari seluruh spesies tumbuhan tersebut, diketahui sekurangkurangnya 9.600 spesies tumbuhan berkhasiat sebagai

tanaman obat dan kurang lebih 300 spesies yang baru digunakan sebagai bahan obat tradisional oleh industri obat tradisional (Depkes RI, 2007). Untuk itu perlu dilakukan pengembangan obat tradisioanal secara berkelanjutan dan terpadu sehingga kekayaan alam Indonesia dapat dimanfaatkan secara maksimal untuk meningkatkan pelayanan kesehatan masyarakat.

Perkembangan obat tradisional di Indonesia sudah lama dikenal di masyarakat. Selain itu, penggunaan obat tradisonal juga telah di gunakan oleh berbagai Negara berkembang. Obat tradisional memiliki beberapa kelebihan antara lain, efek sampingnya relatif rendah, dalam suatu ramuan dengan komponen berbeda memiliki efek saling mendukung, pada satu tanaman memiliki lebih dari satu efek farmakologi serta lebih sesuai untuk penyakit-penyakit metabolik dan degeneratif (Katno, et al. 2002).

Salah satu jenis tumbuhan yang digunakan sebagai obat tradisisonal adalah daun mahkota dewa. Daun mahkota dewa merupakan salah satu tumbuhan yang sering digunakan untuk pengobatan bagi masyarakat untuk pengobatan, seperti kanker, tumor, diabetes (kencing manis), pembengkakan prostad, asam urat, darah tinggi (hipertensi), reumatik, batu ginjal, hepatitis, dan penyakit jantung.

Asam urat erat kaitannya dengan hiperurisemia. Seseorang dikatakan kelebihan asam urat jika kadar asam urat dalam serum orang dewasa lebih dari $7,0 \mathrm{mg} / \mathrm{dL}$ pada pria dan 6,0 $\mathrm{mg} / \mathrm{dL}$ pada wanita. Pola makan yang tidak sehat dalam masyarakat yang berprotein tinggi, terutama protein hewani yang bayak mengandung purin tinggi, menyebabkan penyakit hiperurisemia (kelebihan asam urat) semakin meningkat. Terjadinya peningkatan kadar asam urat dalam darah melewati batas normal akan menimbulkan rasa sakit atau nyeri. Keadaan ini disebut dengan hiperurisemia. Penyakit akibat hiperurisemia dikenal sebagi gout atau penyakit pirai (Pribadi dan Ernawati, 2010). Hasil penelitian yang telah dilakukan sebelumnya, bahwa infusa daging buah mahkota dewa dosis $2,5 \mathrm{~g} / \mathrm{kg} \mathrm{BB}$ efektif menurunkan kadar asam urat darah mencit putih jantan yang dibuat hiperurisemia dengan kalium oksonat dosis $250 \mathrm{mg} / \mathrm{kgBB}$ sekitar 73,77\% (Setiani, 2010). Dari harga IC 50 flavonoid buah mahkota dewa menyatakan bahwa 50\% penghambatan xantin oksidase sama dengan $50 \%$ penurunan produksi asam urat. Jenis flavonoid yang berperan dalam mekanisme penghambatan enzim xantin oksidase adalah flavon dan flavonol (Cos et.al., 1998). Daun mahkota dewa secara empiris juga digunakan oleh masyarakat samarinda untuk mengobati asam urat, karena daun mahkota dewa mengandung senyawa flavonoid, steroid dan terpenoid, polifenol, tanin dan alkaloid.

Berdasarkan uraian di atas, maka perlu dilakukan uji efek ekstrak etanol daun mahkota dewa terhadap penurunan kadar asam urat pada mencit yang diinduksi dengan kombinasi kalium oksonat dosis $300 \mathrm{mg} / \mathrm{Kg}$ BB dan suspensi hati ayam 1,25 mg/Kg BB.

\section{METODE PENELITIAN}

\section{Bahan}

Bahan yang digunakan adalah daun mahkota dewa (Phaleria macrocarpa), mencit betina putih, makanan mencit, Na CMC 0,5\%. Etanol 96\%, aquadest, kalium oksonat Dosis $300 \mathrm{mg} / \mathrm{Kg} \mathrm{BB}$, Suspensi hati ayam Dosis 1,25 mg/KgBB, Allopurinol $100 \mathrm{mg}$. 


\section{Peralatan}

Alat yang digunakan adalah toples maserasi, seperangkat alat rotary evaporator, timbangan analitik, timbangan hewan, kandang hewan, mortir dan stemper, sonde, spuit, gelas ukur, corong, Nesco dan labu takar.

\section{Prosedur}

\section{A. Pembuatan Ekstrak}

Ekstraksi sampel dilakukan dengan metoda maserasi (perendaman). Daun mahkota dewa kering yang telah dirajang, ditimbang sebanyak 600 g. Kemudian masukkan kedalam toples, direndam dengan etanol $80 \%$ selama 3 hari dan disimpan ditempat gelap sambil sesekali diaduk. Maserat diaduk setiap hari dan dilakukan penyaringan. Setelah 3 hari perendaman, disaring dan ampasnya direndam kembali. Penyaringan ini dilakukan sebanyak empat kali. Filtrat etanol yang didapat dari hasil keempat perendaman di atas dipekatkan menggunakan rotari evaporator sampai diperoleh ekstrak kental, kemudian ditimbang.

\section{B. Karakterisasi Sampel}

\section{Penentuan rendemen}

Penentuan rendemen dihitung

dengan rumus :

$$
\text { Rendeman }=\frac{\mathrm{B}}{\mathrm{A}} \times 100 \%
$$

Keterangan:

$$
\begin{aligned}
& A=\text { berat sampel (gram) } \\
& B=\text { berat ekstrak yang diperoleh (gram) }
\end{aligned}
$$

\section{Uji Alkaloid}

Sampel ditambah dengan 2-3 tetes pereaksi Dragendorf, bila bereaksi positif akan menghasilkan endapan jingga, bila ditambah dengan pereaksi meyer akan menghasilkan endapan putih atau keruh.

\section{Uji Flavonoid}

Ekstrak ditambahkan beberapa tetes

$\mathrm{HCl}$ pekat dan sedikit serbuk magnesium. Bila terjadi perubahan warna merah, jingga atau kuning menunjukkan sampel mengandung flavonoid.

\section{Uji Steroid dan Terpenoid}

Ekstrak ditambahkan dengan $2 \mathrm{ml}$ kloroform, $2 \mathrm{ml}$ asam asetat anhidrat dan $3 \mathrm{ml}$ asam sulfat pekat. Terbentuknya warna hijau biru, cincin merah kecokalatan menunjukkan adanya tritetpenoid dan steroid.

\section{Uji Saponin}

Ekstrak ditambahkan dengan $1 \mathrm{ml}$ aquades didalam tabung reaksi, kemudian dikocok dan diperhatikan apakah terdapat buih yang tahan lama pada permukaan cairan dan tidak hilang pada saat penambahan 1 tetes asam klorida $2 \mathrm{~N}$. Terbentuknya buih tersebut menunjukkan adanya saponin.

\section{Uji Tanin}

Ekstrak ditambahakan gelatin, lalu beberapa tetes ferilklorida $1 \%$. Terbentuknya warna coklat kehijauan atau biru kehitaman menunjukan adanya tanin. 


\section{Uji Fenol}

Ekstrak ditambahakan beberapa tetes ferilklorida $1 \%$. Terbentuknya warna coklat kehijauan atau biru kehitaman menunjukan adanya fenol.

\section{Penyiapan Hewan Percobaan}

Hewan percobaan yang digunakan adalah mencit putih yang sehat berumur 2-3 bulan dengan berat badan 20-30 gram kemudian di aklimatisasi selama 1 minggu yang bertjuan agar mencit beradaptasi dengan lingkungan baru.

Untuk mendapatkan hewan hiperurisemia mencit diberi homogenat hati ayam segar $1,25 \mathrm{~g} / 20 \mathrm{~g}$ BB dan diinduksi dengan kalium oksonat $300 \mathrm{mg} / \mathrm{Kg}$ BB. Hewan uji dikatakan hiperurisemia jika kadar asam urat darahnya $\geq 3,0 \mathrm{mg} / \mathrm{dL}$.

\section{Pembuatan Sediaan}

\section{Makanan Diet Purin Tinggi (MDPT)}

Hati ayam segar $100 \mathrm{mg}$ dicuci, dipotong kecil-kecil kemudian diblender dengan penambahan air suling $25 \mathrm{ml}$, diblender hingga halus, kemudian saring homogenat dan dimasukkan dalam wadah (Murny, 2011). Volume homogenat hati yang diberikan ke mencit adalah $0,5 \mathrm{ml} / 20 \mathrm{~g} \mathrm{BB}$ atau dosis $1,25 \mathrm{~g} / 20 \mathrm{~g} \mathrm{BB}$.

\section{Allopurinol}

Dosis allopurinol yang digunakan adalah $100 \mathrm{mg}$. Sediaan pembanding Allopurinol dibuat dengan konsenterasi larutan stok $0,52 \mathrm{mg} / \mathrm{mL}$. Allopurinol disuspensikan menggunakan Na CMC 0,5\%.

\section{Kalium Oksonat}

Dosis kalium oksonat yang digunakan $300 \mathrm{mg} / \mathrm{Kg}$ BB. Dilarutkan dengan $\mathrm{Na}$ CMC 0,5\%, dengan konsentersi larutan stok $60 \mathrm{mg} / 5 \mathrm{~mL}$.

\section{E. Metode Pengujian}

Tiap kelompok diukur kadar asam urat dengan meneteskan darah yang berasal dari vena ekor mencit pada test trip, tunggu beberapa detik sampai darah merata pada zona reaksi dengan otomatis. Dalam 10 detik, kadar asam urat dalam darah mencit akan tampil pada layar alat. Kemudian mencit diinjeksikan dengan potassium oxonat dosis $300 \mathrm{mg} / \mathrm{kg}$ BB secara intraperitoneal (i.p.). Satu jam kemudian diberi MDPT, setelah 2 jam kemudian diukur kadar asam urat darah mencit. Setelah diukur kadar asam uratnya masing-masing mencit diberi perlakuan sebagai berikut:

a) Kelompok I : Diberikan suspensi CMC 0,5\%

b) Kelompok II : Diberikan suspensi allopurinol dosis 0,26 mg/20 g BB

c) Kelompok III : Diberikan suspensi EEHS dosis $25 \mathrm{mg} / \mathrm{kg}$ BB

d) Kelompok IV : Diberikan suspensi EEHS dosis $50 \mathrm{mg} / \mathrm{kg} \mathrm{BB}$

e) Kelompok V : Diberikan suspensi EEHS dosis $75 \mathrm{mg} / \mathrm{kg} \mathrm{BB}$

f) Kelompok V : Diberikan suspensi EEHS dosis $100 \mathrm{mg} / \mathrm{kg} \mathrm{BB}$

g) Kelompok V : Diberikan suspensi EEHS dosis $125 \mathrm{mg} / \mathrm{kg} \mathrm{BB}$

Satu jam kemudian diukur kadar asam urat darah mencit, lalu diukur kembali pada jam ke 4, 5,6 dan 7.

Data dari hasil penelitian ini dianalisa secara statistik dengan ANOVA dua arah. Analisis data kemudian dilanjutkan dengan Uji Wilayah Berganda Duncan (Duncan's multiple range test) dan kebermaknaan diambil pada tingkat kepercayaan $95 \%$. 


\section{HASIL DAN PEMBAHASAN}

Penelitian ini menggunakan sampel daun mahkota dewa yang telah dikeringkan. Sampel kering digunakan agar sampel mudah dibersihkan dari pengotor juga mudah disimpan kembali. Selanjutnya sampel kering dimaserasi menggunakan alkohol. Maserasi dipilih karena dapat digunakan untuk ekstraksi sampel dalam jumlah banyak, tidak memerlukan perlakuan khusus, pengerjaannya mudah, sederhana dan tidak memerlukan pemanasan sehingga baik untuk simplisia yang mengandung zat aktif yang tidak tahan terhadap pemanasan.

Selanjutnya sampel dimaserasi menggunakan etanol. Etanol digunakan karena etanol adalah pelarut universal yang dapat melarutkan hampir semua senyawa baik yang bersifat polar, semi polar dan non polar. Selain itu, etanol dapat menjaga stabilitas zat dengan cara menghambat kerja enzim dan bersifat antiseptik sehingga dapat menghambat pertumbuhan kapang dan jamur. Pelarut etanol yang digunakan adalah etanol $80 \%$ karena sampel yang digunakan adalah sampel kering. Adanya kandungan air dari etanol $80 \%$ mampu melisis sel sampel sehingga penetrasi pelarut ke dalam sel sampel lebih mudah dan tersari lebih baik. Sampel daun mahkota dewa yang dimaserasi sebanyak 600 gram. Perendaman sampel dilakukan selama 3 hari sambil sesekali di aduk dan dilakukan empat kali pengulangan. Hal ini bertujuan untuk menarik senyawa-senyawa aktif berkhasiat yang terkandung di dalam sampel. Dilakukan penguapan pelarut pada maserat. Selanjutnya ekstrak dipekatan dengan rotary evaporator untuk menguapkan pelarut dan air yang masih tersisa sehingga didapatkan ekstrak kental dengan berat konstan, Ekstrak kental yang diperoleh adalah sebanyak 125 gram (Tabel 1).

Hasil rendemen yang diperoleh sebesar 20,3\%. Hasil uji fitokimia menunjukkan adanya senyawa flavonoid, alkaloid, tanin, fenol, steroid dan terpenoid (Tabel 2). Rendemen menunjukkan persentase kadar ekstrak yang diperoleh dari sampel kering yang digunakan untuk pembuatan ekstrak. Besar kecilnya nilai rendemen menunjukkan efektivitas proses ekstraksi.

Tabel 1. Hasil Penentuan Rendemen Ekstrak Etanol Daun Mahkota Dewa

\begin{tabular}{cc}
\hline Sampel & Jumlah (gram atau \%) \\
\hline Simplisia Kering & 600 gram \\
Ekstak & 125 gram \\
\% Rendemen & $20,3 \%$ \\
\hline
\end{tabular}

Tabel 2. Hasil uji Fitokimia

\begin{tabular}{cc}
\hline Pemeriksaan & Hasil \\
\hline Alkaloid & $(+)$ \\
Flavonoid & $(+)$ \\
Tanin & $(+)$ \\
Saponin & $(-)$ \\
Fenol & $(+)$ \\
Steroid dan Terpenoid & $(+)$ \\
\hline
\end{tabular}


Tabel 3. Rata-rata Pengukuran Kadar

\begin{tabular}{cccccc}
\hline Kel & \multicolumn{5}{c}{ Waktu (menit) } \\
\cline { 2 - 6 } & 60 & 90 & 120 & 150 & 180 \\
\hline I & 9,4 & 11,4 & 10,5 & 9,4 & 7,8 \\
II & 7,9 & 7,3 & 4,8 & 3,3 & - \\
III & 8,3 & 7,4 & 6,9 & 5,4 & 4,0 \\
IV & 10,6 & 7,6 & 5,6 & 7,9 & 3,1 \\
V & 9,0 & 7,6 & 6,7 & 5,6 & 3,6 \\
VI & 7,5 & 8,3 & 7,7 & 6,0 & 4,6 \\
VII & 7,4 & 9,3 & 7,2 & 5,7 & 3,7 \\
\hline
\end{tabular}

Penginduksian mencit dilakukan dengan pemberian makanan diet purin tinggi (MDPT) yaitu homogenat hati ayam segar. Hati hati ayam mempunyai kandungan purin nomor 2 setelah otak, setiap 100 gram hati ayam mengandung 150-1000 mg purin. Di dalam tubuh, seluruh basa purin baik yang berasal dari tubuh sendiri (sintesa asam nukleat) ataupun yang berasal dari makanan akan dikatabolisme menjadi asam urat yang merupakan produk akhir dari

metabolisme purin. Basa purin di dalam tubuh yaitu adenin dan guanin masing masing akan diubah menjadi hipoxantin dan xantin. Selanjutnya dengan bantuan enzim xantin oksidase, hipoxantin dan xantin akandiubah menjadi asam urat. Pada kebanyakan mamalia reaksi ini berlanjut dengan pengubahan asam urat menjadi allantoin dengan bantuan enzim urikase.

Hewan uji (yang telah diperiksa kadar asam urat darah awal) diberi perlakuan dengan memberi secara oral homogenat hati ayam 1,25 g /20 gBB dan kalium oksonat 300 $\mathrm{mg} / \mathrm{KgBB}$, untuk meningkatkan kadar asam urat darah guna memperoleh kondisi hiperurisemia. Kalium oksonat merupakan penghambat enzim, urikase yang bisa mengubah asam urat menjadi alantoin yang larut dalam air. Kalium oksonat perlu diinduksikan agar kadar asam urat tidak berkurang akibat pengonversian dari enzim urikase.

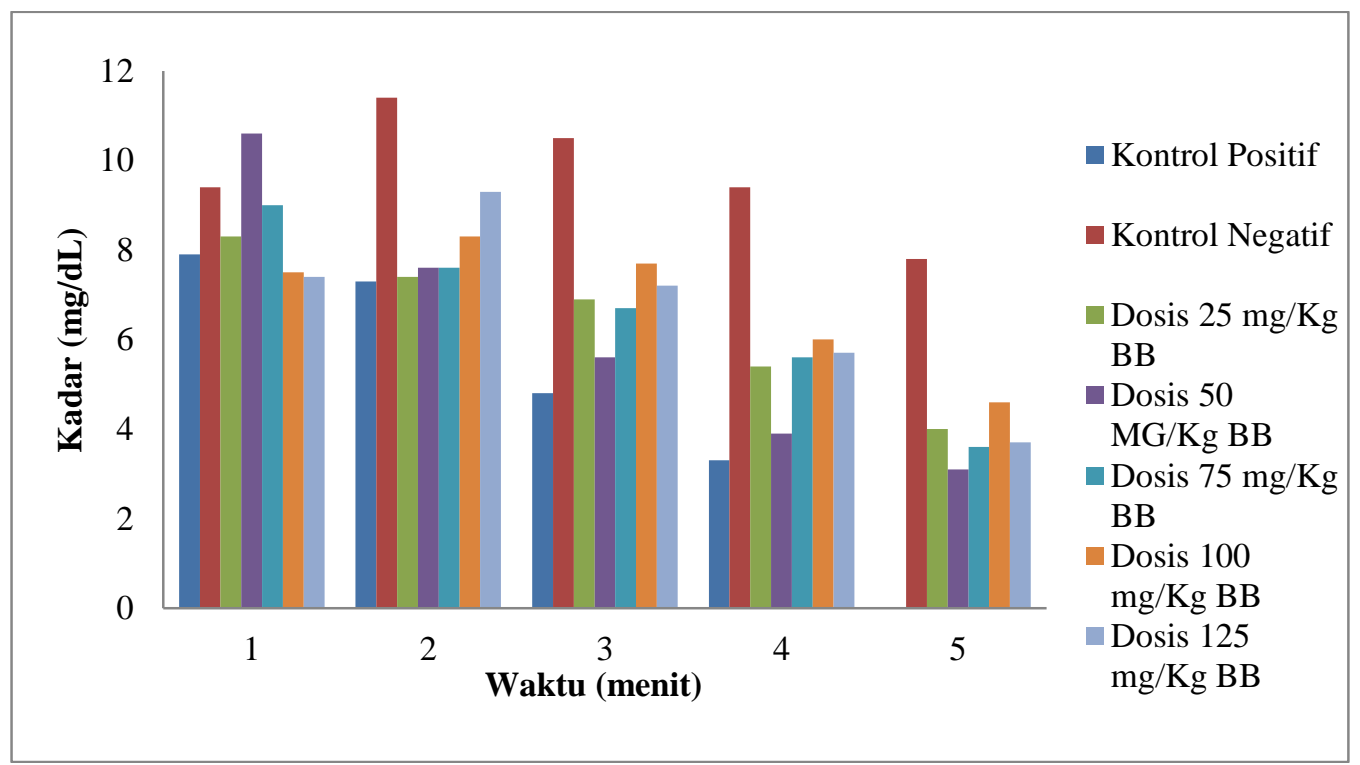

Gambar 1. Diagram Penurunan Kadar asam urat Darah Mencit 
Berdasarkan diagram diatas dapat dilihat dari masing masing perlakuan uji dengan variasi dosis yang berbeda ekstrak memberikan aktivitas penurunan kadar asam urat. Dapat dilihat bahwa ekstrak memiliki efek terhadap penurunan kadar asam urat, hal ini dapat dilihat dengan membandingkannya dengan pemberian suspense Na CMC 0,5\%, dimana pada pemberian suspensi $\mathrm{Na}$ CMC $0,5 \%$ memiliki waktu yang lebih lama dalam menurunkan kadar asam urat hingga mencapai kadar terendahnya $(<3,0 \mathrm{mg} / \mathrm{dL})$. Berbeda dengan pada pemberian ekstrak daun mahkota dewa memiliki pengaruh dalam menurunkan kadar asam urat darah pada jam ke 5. Sedangkan untuk kontrol positif menurunkan kadar asam urat lebih cepat yaitu pada jam ke-4, sehingga dapat disimpulkan bahwa ekstrak daun mahkota dewa memiliki efek antihiperurisemia pada mencit yang diinduksi hati ayam dan kalium oksonat. Mekanisme kerja dari ekstrak mungkin mirip dengan allopurinol yaitu dengan menghambat kerja enzim xantin oksidase atau kalium oksonat sehingga asam urat dapat diubah menjadi allantoin yang larut dalam urin. Kandungan metabolit sekunder daun mahkota dewa yaitu flavonoid, mampu menghambat system kerja enzim xantin oksidase, xantin oksidase adalah enzim yang mengkatalisasi pembentukan xantin dan hipoxantin menjadi produk asam urat.

Berdasarkan penjelasan diatas menujukkan bahwa ekstrak daun mahkota dewa memiliki efek antihiperurisemia, hal tersebut dibuktikan dengan variasi dosis ekstrak yang dapat menurunkan kadar asam urat darah mencit yang mendekati kadar normalnya dalam waktu yang sama yaitu pada jam ke-5. Oleh karena itu perlu dilakukan pencarian dosis efektif. Dosis efektif adalah dosisi minimal ekstrak yang memiliki kemampuan menurunkan kadar asam urat terbaik. Adapun hasil rata-rata kadar asam urat tiap perlakuan dapat dilihat pada Tabel 4 berikut ini.

Tabel 4. Data kadar rata-rata kadar asam urat mencit

\begin{tabular}{cc}
\hline Perlakuan & $\begin{array}{c}\text { Rerata Kadar Asam Urat } \\
(\mathrm{mg} / \mathrm{dL})\end{array}$ \\
\hline KN (Na CMC 0,5\%) & 23,91 \\
Ekstrak dosis $25 \mathrm{mg} / \mathrm{Kg} \mathrm{BB}$ & 19,22 \\
Ekstrak dosis $50 \mathrm{mg} / \mathrm{Kg} \mathrm{BB}$ & 18,56 \\
Ekstrak dosis $75 \mathrm{mg} / \mathrm{Kg} \mathrm{BB}$ & 18,82 \\
Ekstrak dosis $100 \mathrm{mg} / \mathrm{Kg} \mathrm{BB}$ & 20,58 \\
Ekstrak dosis $125 \mathrm{mg} / \mathrm{Kg} \mathrm{BB}$ & 19,58 \\
\hline
\end{tabular}

Berdasarkan tabel diatas. Menunjukkan bahwa kadar asam urat tiap perlakuan memiliki perbedaan terutama antara Kontrol negatif dengan dosis ekstrak, dengan demikian dapat disimpulkan dengan adanya pemberian ekstrak etanol daun mahkota dewa sebagai antihiperurisemia yaitu dosis $50 \mathrm{mg} / \mathrm{Kg} \mathrm{BB}$, dosis ini mampu menurukan kadar asam urat lebih rendah dibandingkan dosis lainnya.

Data hasil pengukuran kadar asam urat yang diperoleh kemudian dianalisis dengan uji statistik menggunakan ANAVA 2 Arah. Dari analisis anova dua arah dantara kelompok dan dosis didapatkan hasil yang signifikan $(\mathrm{P}<0,05)$. Hal ini berarti terdapat pengaruh antara faktor perbedaan dosis tiap kelompok memberi perbedaan yang bermakna. Sedangkan analisis anova dua arah pada waktu (lama pemberian) memberikan hasil yang signifikan $(\mathrm{P}<0,05)$. Selanjutnya pada interaksi antara kelompok dosis dan waktu, hasil uji analisis anova dua arah signifikan $(\mathrm{P}<0,05)$.

Analisis dari anova dua arah dilanjutkan dengan uji DMRT (Duncan's Multiple Range Test). Uji Duncan dilakukan terhadap faktor dosis dan waktu. Hasil uji Duncan terhadap faktor dosis menunjukkan bahwa penurunan kadar asam urat kelompok uji dosis 50, 25, 75, 100 dan $125 \mathrm{mg} / \mathrm{kgBB}$ berbeda secara signifikan dengan kelompok 
pembanding (Tabel 4). Hal ini menjelaskan bahwa ekstrak memiliki efek antihiperurisemia namun dosis terkecil yaitu $50 \mathrm{mg} / \mathrm{Kg}$ BB memiliki efek yang lebih baik daripada dosis 25,75,100 dan $125 \mathrm{mg} / \mathrm{Kg}$ BB. Hal ini menujukkan bahwa semakin tinggi dosis ekstrak maka semakin lemah aktifitasnya, hal ini mungkin disebabkan oleh senyawa-senyawa yang bersifat antagonis terhadap senyawa aktif semakin besar jumlahnya sehingga menghambat kerja senyawa aktif untuk menunjukkan efek farmakologinya.

Berdasarkan hasil uji stastitik diata menyatakan dosis efektif ekstrak yang lebih baik adalah dosis $50 \mathrm{mg} / \mathrm{Kg}$ BB. Kemudian dosis tersebut dibandingan dengan allopurinol memiiki efek yang sama baiknya dalam menurunkan kadar asam urat melalui uji t, dimana $(\mathrm{P}<0,05)$ yang artinya tidak ada perbedaan yang bermakna.

\section{KESIMPULAN}

1. Pemberian ekstrak etanol daun mahkota dewa dengan dosis $25 \mathrm{mg} / \mathrm{kgBB}, 50$ $\mathrm{mg} / \mathrm{kgBB}, 75 \mathrm{mg} / \mathrm{kgBB}, 100 \mathrm{mg} / \mathrm{kgBB}$ dan $125 \mathrm{mg} / \mathrm{kgBB}$ dapat menurunkan kadar asam urat pada keadaan hiperurisemia secara bermakna $(\mathrm{P}<0.05)$.

2. Pemberian ekstrak etanol daun mahkota dewa dengan dosis $50 \mathrm{mg} / \mathrm{kgBB}$ merupakan dosis efektif dalam menurunkan kadar asam urat darah mencit.

\section{DAFTAR PUSTAKA}

Coss P, Ying L, Calomme MJP, Cimanga K, Van PB, Pieters L, Vlietinck AJ, Vanden BD. 1998. Structure-Activity Relationship and Classification of Flavonoids as Inhibitors of Xanthine Oxidase and Superoxide Scavengers. J.Nat.Prod. (61), p.71-76.

Depkes RI. 2007. Kotranas. Jakarta: Departemen Kesehatan RI. p.4-14.

Katno, Pramono S. 2002. Tingkat Manfaat dan Keamanan Tanaman Obat Tradisional. Universitas Gajah Mada: Yogyakarta

Lovira, Hamzah., Helmi Arifin., dan Asram Ahmad. 2014. Pengaruh ekstrak etanol rambut jagung (Zea mays L.) terhadap kadar asam urat darah mencit putih jantan hiperurisemia. Prosiding Seminar Nasional dan Workshop "Perkembangan Terkini Sains Farmasi dan Klinik IV,p. 282-285

Murny A. 2011. Pengaruh Pemberian Ekstrak Etanol Bungo Timah (Peperomia pellucida L. Kunth) Terhadap Kadar Asam Urat Serum Mencit Jantan yang Diinduksi Potassium Oksonat. Skripsi Sarjana Farmasi. Fakultas Farmasi Universitas Andalas.

Prasetya Y. 2009. Uji Efek Ekstrak Etanol Daun Sirih (Piper Betle L) Terhadap Penurunan Kadar Asam Urat Darah Tikus Putih Jantan yang Diinduksi Kafeina. Skripsi Sarjana Farmasi. Fakultas Kedokteran dan Ilmu Kesehatan Universitas Islam Negeri (UIN) Syarif Hidayatullah Jakarta

Pribadi, F.W., dan Ernawati, D.A. 2010. Efek Catechin Terhadap Kadar Asam Urat, CReaktive Protein(CRP) danMalondialdehid Darah Tikus Putih (Rattus norvegicus) Hiperurisemia. Mandala of Health. 4(1), p.39-46

Setiani,L.A., 2010. Efek Infusa Daging Buah Mahkota Dewa (Phaleriamacrocarpa(Scheff)Boerl.) terhadap penurunan Kadar Asam Urat Darah Mencit Putih Jantan yang Diinduksi Potassium Oxonate. Skripsi. Fakultas Farmasi Universitas Muhammadiyah Surakarta 